\title{
STABILITY OF MICROSPHERE OF SARGASSUM PLAGYOPHYLLUM (MERTENS) J. G. AGARDH EXTRACT PRODUCED BY SPRAY DRYING USING MALTODEXTRIN
}

\author{
EFFIONORA ANWAR*, DYAH AYU RATNA YULIANTI, KURNIA SARI SETIO PUTRI
}

Department of Pharmacy, Faculty of Pharmacy, Universitas Indonesia, Depok, 16424, Indonesia. Email: effionora.anwar@farmasi.ui.ac.id Received: 30 April 2018, Revised and Accepted: 28 October 2018

\begin{abstract}
Objective: This study aimed to determine the stability of microspheres of Sargassum plagyophyllum (brown seaweed) after preparation using spray drying with maltodextrin DE 10-15 and during drying and storage.

Methods: Aqueous extracts of brown seaweed were formulated into microspheres using maltodextrin DE 10-15 as a coating agent. For increasing the stability of polyphenol compounds, spray drying was performed with an inlet temperature of $110^{\circ} \mathrm{C}$. Four microsphere formulations were produced using maltodextrin DE 10-15 at concentrations of $0 \%, 5 \%, 10 \%$, and $15 \%$. The resulting microspheres were then characterized in the assessments of moisture contents, particle size distributions, $\mathrm{pH}$, total phlorotannin contents, and antioxidant activity, and surface morphology was analyzed using scanning electron microscope analyses.
\end{abstract}

Results: Powders that were produced with $0 \%$ and $15 \%$ maltodextrin were more stable at $4{ }^{\circ} \mathrm{C} \pm 2^{\circ} \mathrm{C}$ than at $28^{\circ} \mathrm{C} \pm 2{ }^{\circ} \mathrm{C}$ and $40^{\circ} \mathrm{C} \pm 2^{\circ} \mathrm{C}$. At the lowest temperature, phlorotannin contents were maintained in powders that were prepared with $15 \%$ maltodextrin but were decreased by $10 \%$ in powders that were prepared without maltodextrin.

Conclusion: Maltodextrin DE 10-15 is a suitable coating agent for dry formulations of S. plagyophyllum powder and maintained stability during spray drying at $110^{\circ} \mathrm{C}$ and during storage for 2 months at $4^{\circ} \mathrm{C} \pm 2^{\circ} \mathrm{C}$.

Keywords: Maltodextrin, Microsphere, Phlorotannin, Sargassum plagyophyllum, Spray drying.

(C) 2018 The Authors. Published by Innovare Academic Sciences Pvt Ltd. This is an open access article under the CC BY license (http://creativecommons. org/licenses/by/4. 0/) DOI: http://dx.doi.org/10.22159/ijap.2018.v10s1.83

\section{INTRODUCTION}

Sargassum plagyophyllum is a brown marine macroalgae (Phaeophyta) that is frequently found in tropical and subtropical countries, such as Indonesia, Malaysia, Thailand, and Vietnam [1]. Brown marine alga are rich sources of bioactive phlorotannin polyphenols [2], which are the only group of phenols in brown algae [3] and are formed by the polymerization of phloroglucinol (1,3,5-trihydroxybenzene) monomer units in the acetate-malonate biosynthetic pathway $[4,5]$. Phlorotannins from brown seaweeds have anticancer, anti-inflammation, antioxidant, anti-allergic, antidiabetic, and anti-wrinkle properties [6]. However, like other polyphenols, phlorotannin is sensitive to environmental conditions, including temperature, light, $\mathrm{pH}$, moisture, and oxygen contents, and is therefore susceptible to degradation during product processing and storage [7].

Spray drying is the most widely used process for drying liquids and extracts and has advantages of short contact times with drying medium, high rates of evaporation, and relatively low costs, leading to higher quality products than those produced using conventional drying methods [8]. Spray drying technologies have been widely exploited in the food industry and are used for producing large quantities of microcapsules. In addition, multiple shell materials have been approved for various uses, and these allow exploitation of a range of particle sizes for heat-sensitive food ingredients. During encapsulation, sensitive bioactive compounds are packaged within carrier materials, which protect sensitive core materials from deleterious environmental conditions [9]. Even though spray drying is widely used for producing food powders, some quality losses are associated with the high operating temperatures required.

In this study, microspheres of S. plagyophyllum brown algae extracts were produced using maltodextrin DE $10-15$ as a coating agent in spray drying procedures, and an increased stability of phlorotannins was observed in the drying process and during subsequent storage.

\section{MATERIALS AND METHODS}

Materials

2,2-diphenyl-1-picrilhydrazyl (DPPH, Sigma), phloroglucinol (SigmaAldrich Inc.), Folin-Ciocalteu method (Merck) with phloroglucinol (Sigma), and Maltodextrin DE 10-15 (Sigma) were used.

\section{Instruments}

Brookfield viscometer (Brookfield, USA), sputter coating instrument (Quorum Q150R ES), scanning electron microscope (SEM) (Carl Zeiss EVO MA 10), Mastersizer 2000 (Malvern Instruments Ltd., Worcestershire, UK), pH meter (Eutech Instruments pH 510, Singapore), and moisture tester (AMB 50) wer used.

\section{Seaweed materials}

The brown seaweed S. plagyophyllum was collected from Pantai Binuangeun, Lebak, Banten, Indonesia. The species was identification by an algae researcher from Oseanografi Research Laboratory Center, LIPI Jakarta. The collected seaweed was thoroughly washed in water to remove salts, epiphytes, and sand and was then air-dried in the shade for 3-4 days [10].

\section{Preparation of seaweed extracts}

A dried seaweed $(600 \mathrm{~g})$ was extracted using a maceration method for $24 \mathrm{~h}$ with stirring in $6 \mathrm{~L}$ of demineralized water at room temperature in the dark $[10,11]$. Macerates were then filtered to produce the aqueous extracts of S. plagyophyllum, which were then characterized for $\mathrm{pH}$, total phlorotannin contents, and antioxidant activity.

\section{Determinations of total phlorotannin contents}

Total phlorotannin contents of $S$. plagyophyllum extracts were determined using the Folin-Ciocalteu method with phloroglucinol as a standard [11]. Briefly, aqueous extracts $(5 \mathrm{~g})$ were dissolved in $10 \mathrm{~mL}$ of demineralized water with shaking, and the resulting mixtures 
were centrifuged at $1500 \mathrm{rpm}$ for $4 \mathrm{~min}$ [12]. Supernatants $(0.5 \mathrm{~mL})$ were then mixed with $1.0-\mathrm{mL}$ aliquots of Folin-Ciocalteu reagent (10 times dilution) with vortexing for $5 \mathrm{~s}$, and the reactions were allowed to proceed for $5 \mathrm{~min}$ at $28^{\circ} \mathrm{C}$ in the dark. Subsequently, $2.0-\mathrm{mL}$ aliquots of $7.5 \%$ sodium carbonate $(\mathrm{w} / \mathrm{v})$ were added and incubated in the dark at room temperature for $70 \mathrm{~min}$. The absorbance of sample solutions was then measured at $707 \mathrm{~nm}$ using a spectrophotometer and a calibration curve that was prepared using phloroglucinol, which is the basic structural unit of phlorotannins [11]. Total phlorotannin contents were expressed as mg of phloroglucinol equivalents per $\mathrm{g}$ of aqueous extract [13].

\section{DPPH radical scavenging activity}

The DPPH free radical scavenging activities of $S$. plagyophyllum extracts were determined according to the method described by Mun'im et al. with slight modifications using ascorbic acid as a positive control [14]. Briefly, test samples were dissolved in $2.0-\mathrm{mL}$ aliquots of ethanol and $1.0-\mathrm{mL}$ ethanol solutions of $100-\mu \mathrm{g} / \mathrm{mL}$ DPPH were added with further $1.0-\mathrm{mL}$ aliquots of ethanol. Reaction mixtures were incubated in the dark at $28^{\circ} \mathrm{C}$ for $30 \mathrm{~min}$, and absorbance was determined using a spectrophotometer at $516 \mathrm{~nm}$. Radical scavenging activity was expressed as concentrations of sample required to reduce $50 \%$ DPPH radical by $\left(\mathrm{IC}_{50}\right)$.

\section{Formulation of microspheres from S. plagyophyllum extracts}

Microspheres of $S$. plagyophyllum extracts were formulated using maltodextrin as a coating agent in spray drying procedures with an inlet temperature of $110^{\circ} \mathrm{C}$. Maltodextrin DE $10-15$ was used at $0 \%, 5 \%, 10 \%$, and $15 \%$ and was dissolved gradually in the aqueous extracts of $S$. plagyophyllum during homogenization with a paddle stirrer. Microsphere solutions were then fed into the spray dryer while stirring.

\section{Determinations of the viscosity of microsphere formulations}

Viscosities of microspheres were measured using a Brookfield viscometer at $20 \mathrm{rpm}$ with spindle 1 .

\section{Physical examinations of microspheres}

Microspheres were subjected to sensory observations, and the color, texture, and smell were recorded.

\section{Surface morphology analyses of particles}

Appearances and shapes of powder samples were investigated by placing the powder on aluminum stubs using double-sided adhesive tape. Samples were then coated with gold using a sputter coating instrument (Quorum Q150R ES) at $20 \mathrm{~mA}$ for $60 \mathrm{~s}$ and were then examined using a SEM with an accelerating voltage of $14 \mathrm{kV}$ and secondary electrons.

\section{Particle size distributions}

Particle size distributions of powder samples $( \pm 1.0 \mathrm{~g}$ ) were measured using a Mastersizer 2000.

\section{Moisture contents}

Moisture contents of microspheres were determined using a moisture tester at $105^{\circ} \mathrm{C}-106^{\circ} \mathrm{C}$. Briefly, powder samples $( \pm 500 \mathrm{mg}$ ) were evenly spread over the aluminum plate and were heated for 3-5 min.

\section{pH measurements}

The $\mathrm{pH}$ values of $S$. plagyophyllum extracts and powders were measured using a $\mathrm{pH}$ meter after dissolving 1 -g powder samples in $10 \mathrm{~mL}$ of demineralized water.

\section{Total phlorotannin contents}

Powder samples $( \pm 400 \mathrm{mg}$ ) were dissolved in $10 \mathrm{~mL}$ of demineralized water, and the resulting mixtures were then filtered using filter paper. Phlorotannin contents were determined in the filtrates of microspheres as described above for extracts.

\section{DPPH radical scavenging activity}

DPPH radical scavenging activities of microspheres were determined as described for extracts.

\section{Evaluations of storage stability}

Powders that were prepared without maltodextrin and with 15\% maltodextrin were evaluated after storage under various storage temperatures. Specifically, powder samples were packed into individual glass vials and were stored at $4^{\circ} \mathrm{C} \pm 2^{\circ} \mathrm{C}, 28^{\circ} \mathrm{C} \pm 2^{\circ} \mathrm{C}$, and $40^{\circ} \mathrm{C} \pm 2^{\circ} \mathrm{C}$ for 60 days. Total phlorotannin and moisture contents of stored powders were determined every 14 days, and changes in concentrations of bioactive compounds were calculated and expressed as percentages (\%) of the original contents.

\section{RESULTS AND DISCUSSION}

\section{Analyses of S. plagyophyllum aqueous extracts Total phlorotannin contents}

To develop the analytical procedure, we compared solvent extraction with $25 \%, 50 \%$, and $75 \%(\mathrm{v} / \mathrm{v})$ ethanol and demineralized water and found that polyphenol extraction from seaweeds is best achieved with demineralized water. Total phlorotannin contents of $S$. plagyophyllum water extracts were determined using the Folin-Ciocalteu method. After 70 min incubation under optimal conditions, a calibration curve of phloroglucinol was generated by plotting absorbance measurements against phloroglucinol concentrations, and the adjusted linear equation $\mathrm{y}=0.0043 \mathrm{x}-$ 0.0936 was determined with a correlation coefficient of $r=0.9994$. Total phlorotannin contents of $S$. plagyophyllum extracts were $0.24 \pm 0.00 \mathrm{mg} / \mathrm{g}$ aqueous extract $(0.024 \% \mathrm{w} / \mathrm{w})$.

\section{DPPH radical scavenging activity}

DPPH radical scavenging activities were expressed as $\mathrm{IC}_{50}$ values [15]. S. plagyophyllum aqueous extracts had lower DPPH scavenging activity than ascorbic acid (3.42 ppm), likely reflecting low total phlorotannin contents.

\section{Determination of microsphere viscosities}

Microspheres viscosities decreased with increases in maltodextrin concentrations used during preparation (Table 1). Concentration and temperature of maltodextrin solutions were the two dictators of viscosity, which increased with maltodextrin concentrations and decreased with increasing temperatures [16].

\section{Physical examination}

Microsphere powders of each formula had distinctive odors and fine particles and were slightly moist and had a brown color. Powder colors

Table 1: Physical properties of microspheres

\begin{tabular}{|c|c|c|c|c|c|c|c|c|}
\hline $\begin{array}{l}\text { Formulation } \\
\text { code }\end{array}$ & $\begin{array}{l}\text { Viscosity } \\
\text { (cps) }\end{array}$ & $\begin{array}{l}\text { Yield of } \\
\text { powders (g) }\end{array}$ & $\begin{array}{l}\text { Moisture } \\
\text { content (\%) }\end{array}$ & d (90) $(\mu \mathrm{m})$ & pH & $\begin{array}{l}\text { Total phlorotannin content } \\
\text { (mg phloroglucinol/g } \\
\text { sample) }\end{array}$ & $\begin{array}{l}\text { Total phlorotannin } \\
\text { content in the yield } \\
\text { of powders (mg) }\end{array}$ & IC 50 (ppm) \\
\hline F1 & 8 & 3.14 & 7.96 & 5.402 & $10.89 \pm 0.02$ & $10.20 \pm 0.16$ & $32.04 \pm 0.51$ & 6319.38 \\
\hline $\mathrm{F} 2$ & 10 & 11.90 & 7.70 & 9.328 & $10.84 \pm 0.01$ & $3.36 \pm 0.02$ & $39.93 \pm 0.20$ & 49172.40 \\
\hline F3 & 12 & 20.75 & 7.50 & 10.922 & $10.56 \pm 0.02$ & $2.32 \pm 0.02$ & $48.16 \pm 0.39$ & 59945.63 \\
\hline F4 & 15 & 28.62 & 6.07 & 11.840 & $10.52 \pm 0.02$ & $1.89 \pm 0.01$ & $53.95 \pm 0.23$ & 76318.00 \\
\hline
\end{tabular}


were reduced with increasing maltodextrin concentrations and were also influenced by drying temperature [17].
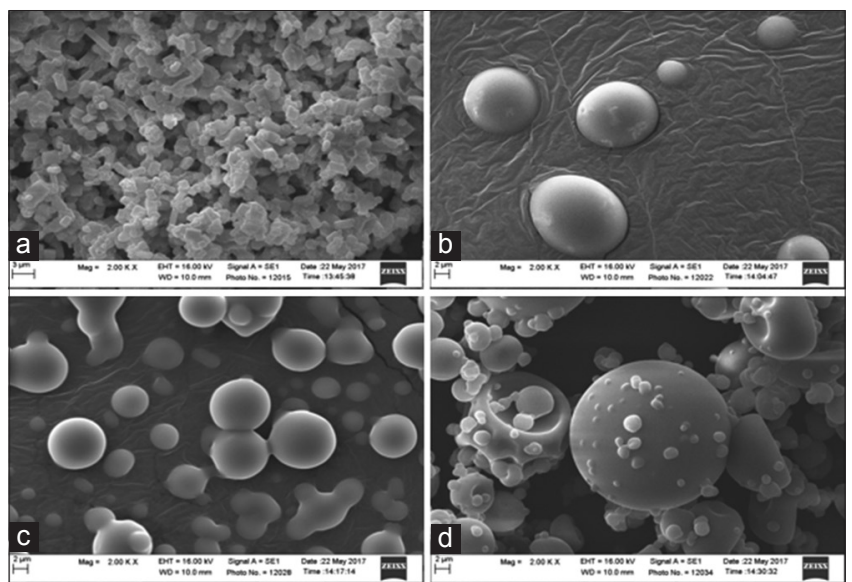

Fig. 1: Particle morphologies of microspheres following preparation with MD 10-15 at (a) $0 \%$, (b) 5\%, (c) 10\%, and (d) $15 \%$; magnification, $\times 2000$
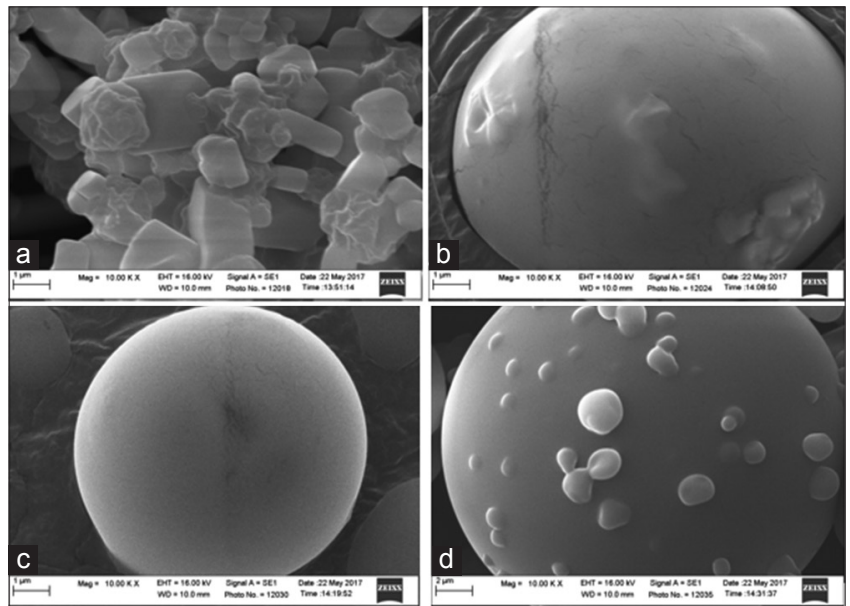

Fig. 2: Particle morphology of microspheres prepared with MD $10-15$ at (a) $0 \%$, (b) 5\%, (c) $10 \%$, and (d) $15 \%$; magnifi cation, $\times 10,000$
Surface morphology of particles

Particle morphologies were assessed using SEM analyses, which revealed spherical particles with cracks and pores on their surfaces following preparation with 5\%,10\%, and 15\% maltodextrin (Figs. 1 and 2). Cracks in particle surfaces were likely caused by high evaporation rates, which can interfere with the formation of films on particles [18]. In general, cracks that form during the encapsulation process can lead to increased contact of encapsulated bioactive compounds with air, thus increasing the chances of oxidation and degradation [19].

\section{Particle size distributions}

Particle size distributions are an important property of powders, particularly, because they directly affect other physical properties of the products. In this study, the particle size distributions of powders were calculated and presented as d(90) values (Table 1). Increasing concentrations of maltodextrin during preparation resulted in wider particle size distribution curves of microspheres and overall increases in particle sizes (Fig. 3).

\section{Moisture contents}

Increasing concentrations of maltodextrin led to decreased moisture contents of the present powders (Table 1). In addition, total soluble solid contents of the extracts increased with maltodextrin concentrations, resulting in decreased availability of water for evaporation, as shown previously $[8,17]$. The stability of the present powders was reduced with increasing moisture contents. In agreement, increased moisture contents reportedly reduced glass transition temperatures, leading to the increased rates of physicochemical change, such as oxidation, in dried products [19]

\section{pH measurements}

Aqueous $S$. plagyophylum extracts had $\mathrm{pH}$ values of $7.82 \pm 0.02$, whereas the $\mathrm{pH}$ of microspheres ranged from $10.52 \pm 0.08$ to $10.89 \pm 0.01$ (Table 1), as shown previously by Caliskan and Dirim. We also show that increasing maltodextrin concentrations during preparation significantly increased the $\mathrm{pH}$ of the resulting powders. In a previous study, some acids were lost due to evaporation during the spray drying process $[1,8]$. However, we did not observe significant effects of increasing maltodextrin concentrations on the $\mathrm{pH}$ of the resulting powders.

\section{Total phlorotannin contents}

Microspheres that were prepared with 15\% maltodextrin DE 10-15 had higher phlorotannin contents than those prepared with lower maltodextrin concentrations (Table 1), and these differences were significant. As carbohydrate matrices, maltodextrins increase the glass
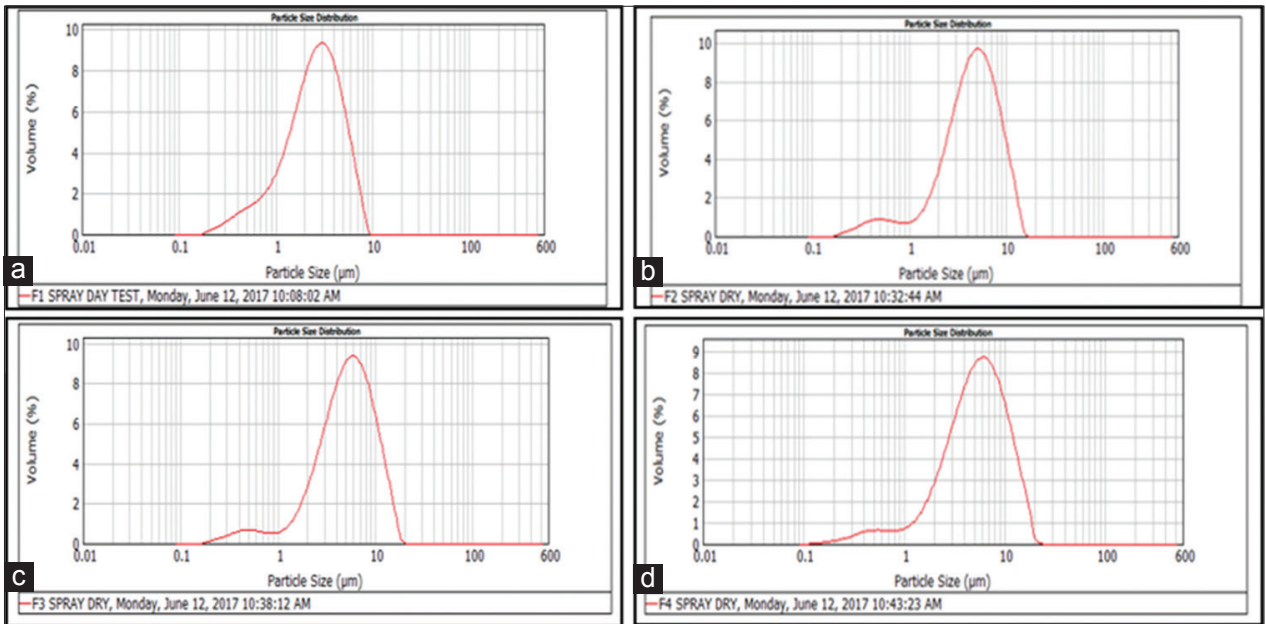

Fig. 3: Particle size distributions of microspheres prepared with MD 10-15 at (a) 0\%, (b) 5\%, (c) 10\%, and (d) $15 \%$ 
Table 2: Effects of storage conditions on the retention of phlorotannins and moisture in microspheres; data are presented as means of three measurements

\begin{tabular}{|c|c|c|c|c|c|c|c|c|c|c|c|c|}
\hline \multirow[t]{3}{*}{ Weeks } & \multicolumn{6}{|c|}{ Total phlorotannin content $(\%)$} & \multicolumn{6}{|c|}{ Moisture content (\%) } \\
\hline & \multicolumn{3}{|l|}{ F1 } & \multicolumn{3}{|l|}{ F4 } & \multicolumn{3}{|l|}{$\mathbf{F 1}$} & \multicolumn{3}{|l|}{ F4 } \\
\hline & $4^{\circ} \mathrm{C}$ & $28^{\circ} \mathrm{C}$ & $40^{\circ} \mathrm{C}$ & $4^{\circ} \mathrm{C}$ & $28^{\circ} \mathrm{C}$ & $40^{\circ} \mathrm{C}$ & $4^{\circ} \mathrm{C}$ & $28^{\circ} \mathrm{C}$ & $40^{\circ} \mathrm{C}$ & $4^{\circ} \mathrm{C}$ & $28^{\circ} \mathrm{C}$ & $40^{\circ} \mathrm{C}$ \\
\hline 0 & 1.00 & 1.00 & 1.00 & 0.18 & 0.18 & 0.18 & 7.96 & 7.96 & 7.96 & 6.07 & 6.07 & 6.07 \\
\hline 2 & 0.99 & 0.99 & 0.98 & 0.18 & 0.18 & 0.18 & 7.94 & 8.16 & 6.77 & 6.13 & 6.16 & 5.96 \\
\hline 4 & 0.93 & 0.92 & 0.90 & 0.18 & 0.18 & 0.18 & 8.2 & 8.34 & 5.76 & 6.35 & 7.15 & 5.56 \\
\hline 6 & 0.92 & 0.89 & 0.88 & 0.18 & 0.17 & 0.18 & 8.64 & 8.77 & 5.17 & 6.55 & 7.39 & 5.36 \\
\hline
\end{tabular}

transition temperature of dried products, thereby trapping the active compounds in a vitreous phase that protects against temperature, stickiness, collapse, and enzymatic or chemical changes such as oxidation [19].

\section{DPPH radical scavenging activity}

In our radical scavenging assays, microspheres had lower DPPH scavenging activity than ascorbic acid $\left(\mathrm{IC}_{50}, 3.42 \mathrm{ppm}\right.$; Table 1$)$. Moreover, increased concentrations of maltodextrin, which has no free-radical scavenging activity, resulted in lower DPPH scavenging activities. These data suggest that the low free radical scavenging activities under these conditions correspond with low phlorotannin contents of aqueous S. plagyophyllum extracts. Moreover, exposure to higher temperatures may have adversely affected the chemical structures of phenols by causing degradation or synthesis of different forms [20-23].

\section{Storage stability evaluation}

Total phlorotannin and moisture contents of powders that were produced in the presence of $0 \%$ and $15 \%$ maltodextrin were determined at $4^{\circ} \mathrm{C} \pm 2^{\circ} \mathrm{C}, 28^{\circ} \mathrm{C} \pm 2^{\circ} \mathrm{C}$, and $40^{\circ} \mathrm{C} \pm 2^{\circ} \mathrm{C}$ for 60 days (2 months). After preparation with $0 \%$ and $15 \%$ maltodextrin, powders were more stable at $4^{\circ} \mathrm{C} \pm 2^{\circ} \mathrm{C}$ than at $28^{\circ} \mathrm{C} \pm 2^{\circ} \mathrm{C}$ and $40^{\circ} \mathrm{C} \pm 2^{\circ} \mathrm{C}$. In addition, we observed significant decreases in total phlorotannin contents when maltodextrin was not used. At $4^{\circ} \mathrm{C} \pm 2^{\circ} \mathrm{C}$, phlorotannin contents were maintained in powders produced with $15 \%$ maltodextrin, whereas a $10 \%$ loss of phlorotannin contents followed storage of powders that were made without maltodextrin. Moisture contents in powders produced without maltodextrin and with $15 \%$ maltodextrin increased over each 14-day period of storage at $4^{\circ} \mathrm{C} \pm 2^{\circ} \mathrm{C}$ and $28^{\circ} \mathrm{C} \pm 2^{\circ} \mathrm{C}$, whereas moisture contents decreased during storage at $40^{\circ} \mathrm{C} \pm 2^{\circ} \mathrm{C}$. Powders that were prepared without maltodextrin had higher changes in moisture contents than those prepared with $15 \%$ maltodextrin (Table 2).

\section{CONCLUSION}

Microspheres that were produced using 15\% maltodextrin DE 1015 had higher phlorotannin contents than those produced without maltodextrin. Stability of microsphere powders was assessed in terms of the loss of bioactive compounds and moisture and differed significantly between tested storage temperatures. In particular, powders that were produced with $0 \%$ and $15 \%$ maltodextrin were more stable at $4^{\circ} \mathrm{C} \pm 2^{\circ} \mathrm{C}$ than at $28^{\circ} \mathrm{C} \pm 2^{\circ} \mathrm{C}$ and $40^{\circ} \mathrm{C} \pm 2^{\circ} \mathrm{C}$, indicating that long-term storage is best achieved using a refrigerator $\left(4^{\circ} \mathrm{C} \pm 2^{\circ} \mathrm{C}\right)$. Taken together, the present data show that spray drying using maltodextrin as an encapsulating agent with an inlet temperature of $110^{\circ} \mathrm{C}$ produces stable microspheres of the $S$. plagyophyllum aqueous extract as indicated by changes in contents of bioactive compounds and moisture during storage for 60 days.

\section{CONFLICTS OF INTEREST}

The authors declared that they no conflicts of interest.

\section{REFERENCES}

1. Chan YY, Kim KH, Cheah SH. Inhibitory effects of sargassum polycystum on tyrosinase activity and melanin formation in B16F10 murine melanoma cells. J Ethnopharmacol 2011;137:1183-8.

2. Shin T, Ahn M, Hyun JW, Kim SH, Moon C. Antioxidant marine algae phlorotannins and radioprotection: A review of experimental evidence. Acta Histochem 2014;116:669-74.

3. Sathya R, Kanaga N, Sankar P, Jeeva S. Antioxidant properties of phlorotannins from brown seaweed Cystoseira trinodis (Forsskal) C. Agardh. Arab J Chem 2011;10:S2608-14.

4. Li Y, Wijesekara I, Li Y, Kim S. Phlorotannins as bioactive agents from brown algae. Process Biochem 2011;46:2219-24.

5. Kapuge K, Sanjeewa A, Kim E, Son K, Jeon Y. Bioactive properties and potentials cosmeceutical applications of phlorotannins isolated from brown seaweeds: A review. J Photochem Photobiol B Biol 2016;162:100-5.

6. Fang Z, Bhandari B. Effect of spray drying and storage on the stability of bayberry polyphenols. Food Chem 2011;129:1139-47.

7. Caliskan G, Dirim SN. The effect of different drying processes and the amounts of maltodextrin addition on the powder properties of sumac extract powders. Powder Technol 2016;287:308-14.

8. Zokti JA, Baharin BS, Mohammed AS, Abas F. Molecules green tea leaves extract: Microencapsulation, physicochemical and storage stability study. Molecules 2016;21:1-24.

9. Masduqi AF, Izzati M, Prihastanti E. Effect of drying method on chemical content in sargassum polycystum seaweed [Efek metode pengeringan terhadap kandungan bahan kimia dalam rumput laut sargassum polycystum]. Bull Anat dan Fisiol 2014;22:1-9.

10. Ye H, Zhou C, Sun Y, Zhang X, Liu J, Hu Q, et al. Antioxidant activities in vitro of ethanol extract from brown seaweed Sargassum pallidum. Eur Food Res Technol 2009;230:101-9.

11. Koivikko R. Brown Algal Phlorotannins Improving and Applying Chemical Methods. Turku: Department of Chemistry University of Turku; 2008

12. Quiros AR, Frecha-Ferreiro S, Vidal-Perez AM, LopezHernandez J. Antioxidant compounds in edible brown seaweeds. Eur Food Res Technol 2010;231:495-8.

13. Kim J, Yoon M, Yang H, Jo J, Han D, Jeon YJ, et al. Enrichment and purification of marine polyphenol phlorotannins using macroporous adsorption resins. Food Chem 2014;162:135-42.

14. Mun'im A, Negishi O, Ozawa T. Antioxidative compounds from Crotalaria sessiliflora. Biosci Biotechnol Biochem 2003;67:410-4.

15. Molyneux P. The use of the stable free radical diphenylpicryl- hydrazyl (DPPH) for estimating antioxidant activity. Songklanakarin J Sci Technol 2004;26:211-9.

16. Pycia K, Juszczak L, Gałkowska D, Witczak M, Jaworska G. Maltodextrins from chemically modified starches as agents affecting stability and rheological properties of albumin foam. Selected physicochemical properties. Carbohydr Polym 2016;146:301-9.

17. Caliskan G, Dirim SN. The effects of the different drying conditions and the amounts of maltodextrin addition during spray drying of sumac extract. Food Bioprod Process 2013;91:539-48.

18. Tan SP, Kha TC, Parks SE, Stathopoulos CE, Roach PD. Effects of the spray-drying temperatures on the physiochemical properties of an encapsulated bitter melon aqueous extract powder. Powder Technol 2015;281:65-75

19. Ramírez MJ, Giraldo GI, Orrego CE. Modeling and stability of polyphenol in spray-dried and freeze-dried fruit encapsulates. Powder 
Technol 2015;277:89-96

20. Mishra P, Mishra S, Mahanta CL. Effect of maltodextrin concentration and inlet temperature during spray drying on physicochemical and antioxidant properties of amla (Emblica officinalis) juice powder. Food Bioprod Process 2014;92:252-8.

21. Vijayalakshmi K, Srimathi PK. Investigation of antioxidant potential of quercetion and hesperidin: An in vitro approach. Asian J Pharm Clin
Res 2017;10:83-6.

22. Samran S, Dalimunthe D. The formulation of dry curcuma (Curcuma xanthorrhiza roxb.) extract microcapsules by spray wet microencapsulation techniques. Asian J Pharm Clin Res 2018;11:226-9.

23. Amatrejo S, Tanjung HR. Tinospora extract (Tinospora crispa (L.) Miers.) encapsulation with sodium alginate isolated from brown algae (Sargassum ilicifolium). Asian J Pharm Clin Res 2018;10:267-9. 